\title{
PATRIOTISM AND ARMENIAN STATEHOOD IN THE NORMS OF ARMENIAN LAW
}

\begin{abstract}
The purpose of the article is to study and present the sources of Armenian law that contain provisions on patriotism and Armenian statehood.

To achieve this goal, our task is to investigate the legal and patriotic labour standards of Hakob and Shahamir Shahamirian's Girk Anvanial Vorogayt Parats (Snare of Glory). It is no secret that the work "Vorogayt Parats" is one of the most important documents of Armenian law, which for the first time in the reality of Armenia presents a holistic and orderly system of norms of various branches of law.

As a result of the research were applied both scientific (analysis, the principle of historicity) and special (comparative-legal) methods.

The study of the above mentioned legal and patriotic norms gives us the opportunity to conclude that they play a key role in the development of our national, legal, political thought and are a kind of value radiating patriotism.

Keywords: patriotism, Armenian law sources, formation of Armenian statehood, Vorogayt Parats, Shahamir Shahamirian, Artsakh, khamsa.

As we know, legal norms of customary law have historically emerged after the formation of families; due to this, matriarchy, and then patriarchy formed. Based on family ties, tribes and clans were later formed.

At the initial stage these were types of peoples' communities, later, due to the emergence and development of labour division and trading relations, appeared state institutions with their mechanisms, leverages, supervision and enforcement bodies. Simultaneously, the legislative law emerged and developed.

Labor refers to such sources of Armenian law that contain patriotism. We will present the legal - patriotic norms of Hakob and Shahamir

Shahamirians" "Vorogayt Parats", we will also briefly address some legal norms containing patriotism, democracy, humanity.

The very existence of the state implies the emergence of law and legal norms, and they are interrelated.

Historically the procedures of emergence and development of the state and the law took place also on Armenian Highland. It was the Armenian world, where Armenian statehood arose and developed.

1 On how the social-philosophical, political-legal worldviews of Armenian enlighteners of the XVIII century are considered in their main works, in particular Shahamir Shahamiryans "Snare of Glory" (1773) see Hovhannisyan, 2001.
\end{abstract}


In the Bible, the Armenian Highland was the earthly paradise, where originated paradise rivers - Araks (Genon), Tigris, Euphrates and Pison (Jorokh) and where Adam and Eve had settled for the first time (Nelson, 2010, p. 8).

Armenian Highland was considered to be the land of legal knowledge and sacred rituals. The climate, geographical location and the abundance of natural resources created good conditions for the emergence and development of crafts and trade. They, naturally, raised the need for legal regulation of trade, economic, social and other relations. Necessarily, legal norms appeared and developed that regulated those relations, the forms and mechanisms of their emergence and adoption. The demand for legal knowledge was subsequently developed.

The state of Armenian forefathers was called Aratta - Araratyan ("Ar" was the highest God). The state was famous for its governing structures and state mechanisms.

The creation of Armens' state relates to $\mathrm{V}$ IV millennia BC. In legends, Prince Hayk Askanaz on the shores of Lake Van, after the victory over the Babylonian King Bel, joined the possessions of Armenian princes within the borders of one kingdom, which was called Hayq-HayastanArmenia.

Thus, the foundation of Haykazuni Kingdom was led. It lasted for 1776 years, following dynastic succession.

The head of the state was the Ruler - monarch. He obeyed Gods and personally communicated with them in the Holy Temple. The Ruler as well was proclaimed God, he was the bearer of absolute power, and only he could rededicate to other persons or groups the implementation of certain parts of his power. The will of the Ruler had the force of law. He was prescribing rights and obligations, and he was creating official po- sitions and governing bodies, he was making appointments. The monarchic title was hereditary. The Armenian monarchic dynasties and kings' forenames of the V-III millennia BC were reflected on clay tablets.

Clay inscription is depicting Armenian Aramazd God as the ruler of the earth, waters and sky demonstrating the attributes of his absolute power. With his left leg, he leans to a seal - Law.

Armenian legal thinking created numerous legal monuments, which had survived to us in the form of hieroglyphs, cuneiforms, stone obelisks, scrolls, printed and manuscript press and in other forms and means.

Ancient philosopher and law-maker Shuruppak in his "Admonitions" demands: "Do not ignore the admonition that I give, do not break the speech that I speak".

"Do not violate your speech; your speech is the basis what you beat with power that will ruin you. Who will ruin houses, will stay under the ruins. Who will rise against men, will be attacked by men. Do not try to catch the water in your hands, your will stay exhausted. Do not steal, do not destroy yourself" (Lambert, 1996).

It is notable that admonitions contain practical, domestic, philosophical, as well as legal thoughts and rules, due to that we will consider them as legislative. Shuruppak attached great importance to public opinion, public evaluations. Guarantees of the significance of a man he is considering as redundancy, subordinate position - "Do not guarantee, in order not to stay dependent... Witness of a man is his city".

Separate norms of "admonitions", as we see, contain direct sanctions: "Thief is a lion, and a slave when caught".

Shuruppak treats with great respect the heroes: "We should bow our heads to heroism". He put heroes on the same level as the sun. 
Law Code of Shulgi of Ar (Ur) - the

Legislator and Philosopher of the

\section{2-21 Century BC}

In this law does not exist the principle of punishment "an eye for an eye, a tooth for a tooth", and instead of physical punishments, it prescribes material damage in the form of fines. This is great progress in his times. It was considered that physical punishments are not only inhumane, but they also deprived people of workability and military service, i.e. of the ability to create goods and to participate in defence of the country.
Article 15: "If a man has cut off another man's limb with a weapon, he is to pay ten shekels of silver".

Article 19: "If a man knocks out a tooth of another man, he should pay 2 shekels of silver for each tooth" (Ayvazyan, 2013, pp. 25-26; Kramer, 1954, p. 23; Gurney \& Kramer, 1965; Finkelstein, 1969).

Bringing brief examples from ancient legal norms, now we will specifically present Shahamirian's "Vorogayt Parats". In this treasury of constitutional law, Shahamirians expressed all their conscious and subconscious patriotism.

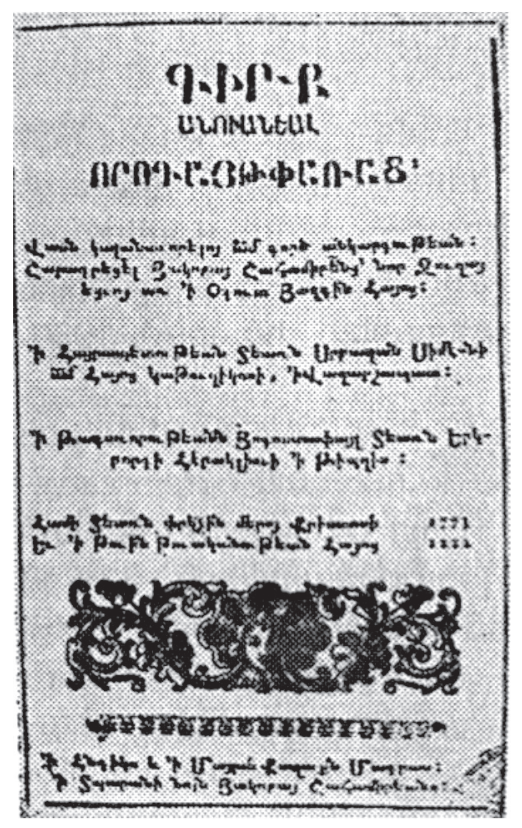

"Vorogayt Parats" in 1760 was started and in 1773 was completed by one of the world's top legal thinkers, the outstanding representative of Indian-Armenian colony Hakob Shahamirian. His father, Shahamir Shahamirian, greatly helped and assisted him in creating the constitution.

Shahamirian titled his work "Constitution for the governance of Armenians, Armenian world", "Vorogayt Parats". It consists of 521 ar- ticles, 25 per cent of which relate to constitutional law; particularly the legal norms referring to power, governing bodies, their organization and operation. This project should have become the constitution of the liberated Armenia he was dreaming about, which would be proclaimed the sovereignty of Armenian national statehood and apostolic church.

This project of the Armenian constitution was created and published 14 years before the 
Constitution of the United States of America and 18 years before the Constitution of France. It remained a project because the Armenian liberation movement did not end in victory.

From the letter addressed by Shahamir Shahmirian to Hovsep Arghutyants (Argutinsky, Primate of Diocese) on 3 September 1786 (preserved in Matenadaran, manuscript number 2699, page 98) we are becoming aware that Prince Potemkin commanded to translate into Russian and publish "Vorogayt Parats".

Arghutyants considered "Vorogayt Parats" to be a treasure (Arghutyan, n.d.), political and legal genius of the Armenian nation. In reality, it is a vivid example of the new ideology of 17-18 centuries.

The process of adoption of the idea of a legal state which is guided by the standards of democracy, legitimacy, representative government and free entrepreneurship is usually referred to the era of English and French revolutions, while they were clearly and vividly formulated in "Vorogayt Parats".

Shahamirian was of the opinion that the failure of Armenian statehood was caused by violations of lawfulness and legal order, as well as disobediences. "Only laws should be the Armenians' king and rule the Armenian land" (Avagyan, 2002, p. 37), - he is writing.

This is based on the priority principle that the Armenian nation can be saved by the legislative body elected in the result of joint national will, and the laws adopted by it; they should derive from nature and reason - from divine laws; they should act following the social morality and prosperity principles.

A question is raised: what did cause the creation of the project of the Armenian statehood constitution? What did make it valuable? What practical importance did it have? In order to an- swer the above-mentioned questions, let us analyze some episodes of Armenian liberating movement of the mentioned period.

The recreation of Armenian statehood and its preservation is a philosophical and political theory. It directly influenced the emergence and development of national thinking, the system of Armenian self-governance. The national ideology and the tasks of the state policy related to it, its practical use are closely connected to the law and legislation, the formation and influence of their epistemological and scientific purposes. The attachment of great importance to the lawfulness approved by law makes it worthwhile by very law itself as the expression of the will of nations, peoples, population (in Shahamirian's work, the nation, because only the Armenian had the right to vote).

In the mentioned era, Armenia was divided between Ottoman Turkey and Iran. The second half of the $18^{\text {th }}$ century for progressive forces in Armenia and outside Armenia was the era of the liberation struggle. Shahamirian and collaborates were concerned with the issue of formation of a political system of the future Armenian state. They worked out a full project of the struggle for the liberation of Armenia, the main axle of which was the necessity of joining Georgian King Erakle II and Karabakh meliks ${ }^{2}$.

The program was intended to be implemented due to the military and political assis tance of Russia. Armenian figures in order to

2 There were 5 Karabakh melikdoms, they were also called Khamsa melikdoms: "khamsa" is an Arabian word and means "five". Some nations are still using the word in the mentioned meaning. Muslims, when saying "khamsa", mean five members of Muhammad's family. It also means Saint Mary's hand palm consisting of five fingers, and Muslims mean Fatima who had a mascot meaning (brings success). In case of meliks, "khamsa" also is explained as hand palm consisting of five fingers, and when they are joined and clenched they are becoming a fist. 
implement that purpose worked out two projects between Armenia and Russia, one of them was authored by Hovsep Argutinski ${ }^{3}$, the other - by Shahamirian. The precondition for this programming idea was the Treaty of Georgievsk, and Hovsep Argutinski contributed to its signing: Russia set a protectorate over the Kingdom of Kartli-Kakheti, preserving its self-governance.

In 1786 Erakle II granted to Shahamirian the title of Prince, and the latter suggested the number of reforms in Georgia, due to which the country shortly should become stronger. Highlighting the issue of population growth in Georgia, he advised the king to apply to all Armenians around the world with an address promising discounts, insurance of life and property.

The $19^{\text {th }}$-century famous Armenian historian Aleksand Yeritsyan mentioned that Shahamirian suggested to Erakle II that the King's family, following his example, liberate all the serfs. Shahamirian was even ready to contribute with the necessary amount of money as a ransom price for the villagers belonging to church (Yeritsyan, 1883).

On 15 October 1787 in his letter addressed to Georgian King Erakle II, Shahamirian writes: "Remember, that not the people were created for you ... You were selected by the destiny for your people... and your people prosperity and liberty are your liberty..."

Shahamiryan also sent to Erakle II the coat

Hovsep Argutinski (Hovsep Arghutyan, 1743-1801) archbishop, outstanding representative of Armenian liberation movement. Representative of ArghutyanErkaynabazuk's oldest princely family. In 1773 was the Primate of Diocese of Russian Armenians. Personally knew Catherine II (Catherine the Great). Led active political correspondence with Georgian King Erakle II, Karabalh meliks, Shahamir Shahamirian and other Armenian figures. Actively participated in resettlement of Crimean Armenians and in foundation of New Nakhijevan, was elected Catholicos, but was not anointed, because died suddenly in Tbilisi on the way to Echmiatsin. of arms created by him for the joined state of Armenia and Georgia, designed in gold, diamonds, and asked him to approve it.

Erakle II with his signature and seal approved the template of the coat of arms, and on 4 December 1790 sent it to Shahamirian to Madras, where the King's proclamation was published and distributed in 1000 printing copies (Nersesyan, 1990, pp. 547-548).

Shahamirian had an active correspondence with Catholicos of Gandzasar Simeon Yerevantsi and Karabakh meliks. The national liberation movement headed by Shahamirian called for rebellion, being sure that the rebellion was the only way. Under the Iranian pressure, Shahamirian, together with his associates, was exiled from Georgia. Catholicos Simeon Yerevantsi believed that rebellion was premature, and would deepen the revenge and pressure by despots, leading to grave consequences.

On 15 January 1779, in his letter addressed to Gandzasar Catholicos Hovhannes Shahamirian, following the example in Bible, suggests: "First of all it is needed to recruit from clergy and seculars 12 teachers, instruct them to teach literacy to children, second - oblige everybody to send their children to schools ... in order the youth, by reading books, be able to learn the history of its nation, to be inspired with liberation spirit ... it is necessary to compile "a book of laws that care about the needs of society..." to adopt an obligation of obeying them. Armenians do not reach the condition, as Jewish, Egyptians or Greeks, they partially have national power, which should be protected from those who have a weak will or are selfless" (Nersesyan, 1990, pp. 135-137, 366-373). Speaking about the national power, Shahamirian meant Karabakh melikdoms. He had a dream to create a national state on the territory of five Artsakh melikdoms, in 
future their economic and military power would liberate the whole Armenia. Inspired by these ideas and standards, Armenian nation, especially intellectuals, were fighting for the liberation of Armenia divided between Turkey and Iran. Their legal-political thinking was directed to building an Armenian state. Shahamirian and his associates, for the first time, integrated and structured the Armenian political and legal-legislative democratic ideology, the level of which has not been exceeded up to now. That is a well-balanced mixture of laws and morality in its ideological sense. "If we want to be liberated and to be the lords of our land... protect human honour and dignity, to cleanse the mud of the past, to live with a clear conscience, first of all, we should build our own state order, work out the laws which will coincide with liberty, interests of our nation..., in that case, people would be dependant only on the laws adopted by the people, but not by individuals, when people are governed by laws and not by one individual. Those laws are our lords and our religion, our ruler and our king" (Avagyan, 2002, p. 3).

Shahamirian died in 1797 in India when he was 74 years old. One year later died the King Erakle II. The idea of creating the state - the dream of those outstanding figures remained a project.

Unfortunately, "Vorogayt Parats" did not become the constitution of independent Armenian state and remained just a project, a doctrine with its national content and orientation. It awakened Armenian national legal awareness. The introduction of "Vorogayt Parats" is the highest value of patriotic demonstration of political, national-liberation ideology. "... The most gifted, the most beautiful and the most special is the Land of Ararat, which by its highest Masis mountain was created by the Lord as the king over the earth and all the mountains, which, as the divine paradise became the foremother for our forefather Adam, so Ararat together with Masis became the land for the settlement of our forefather Noah, became a harbour for him. Thus, the Lord gave his blessing to the House of Nakhijevan and the Land of Ararat" (Avagyan, 2002, pp. 31-32).

Roman historian Flavius Josephus (37-100 years) in his work "Antiquities of the Jews" is referring to: "Noah saw that the world is dry of water, and he stayed yet another seven days, released from his ark the animals, and he also left the boat with his family... Armenians call this place Nakhijevan and people living there up to today are showing the preserved remnants of the ark" (Flavius, 1996, p. 14). It was the will of God that Armenian King Abgar, without the preaches of clergies, without prophets and without witnessing magic, believed the word of the incarnation of the living God's son Jesus Nazirite Christ, and for the first time in Armenia in 301, Christianity was adopted as state religion after the magic of Grigor Lusavoritch (Gregory the Illuminator) Pahlavuni.

"Vorogayt Parats" is a democratic, parliamentary republic's constitution based on a fundamental principle that the power derives from people and reports to people. It was based on principles of supremacy of law, the freedom and equality of rights of nations and ethnics, the equal protection of their rights, separation of powers, freedom of religion. It was prescribed that the legislative and executive powers were elected. Shahamirian was referring to fundamental principles of Armenian national ideology, and sources of Armenian law emerged and established during previous historical periods - the natural divine origin of law and legal superiority, freedom, justice, considering a human being with 
its natural rights as a basis for the legislation.

The highest legislative body in Armenia Shahamirian named "Armenian house", there was excluded the presence of foreign nationals, gentiles and cultists, whose occupation of posts also in executive power was forbidden constitutionally. According to "Vorogayt Parats", every citizen regardless of his ethnicity, religion, gender, social and property status, within the law has the rights to freedom of speech, expression of his opinion and of conscious, to the choice of place of residence, to leave the state and other rights. As Christians, the other gentile foreigners also could freely enter Armenia and reside under the protection of the state, paying taxes, dues, accepting Armenian judicial legislation and procedures that prescribed responsibility for their actions.

In the draft of the constitution there were also articles on military rules (proclamation of emergency situations) - including the norms on manufacturing, importing and exporting weapon.

Humane treatment was prescribed for the populated areas, soldiers and population occupied by the Armenian army. The agreements contradicting to natural human rights and laws, as well as limiting human freedom and humiliating human dignity, circulating in that historical period, especially in eastern countries, were proclaimed non-valid.

The $1^{\text {st }}$ Article of the constitution proclaimed the whole territory and natural wealth as Armenia national wealth, also inherited, and only Armenian state had the right to dispose of it, according to the constitution. The right to land ownership and sell had only Armenians who accepted the religion of the church. Foreign nationals and gentiles could use and own land and resources but could not dispose and could not alienate them. According to the mentioned Article, as Armenian borders were considered to be between the Mediterranean, Black and Caspian seas, locating on the territories of Mets Hayk (Kingdom of Armenia) and Cilician State, which "is the heritage of Armenian people, not an inch can be added or diminished from this land, here always should be preserved the Armenian House according to Armenian constitution". Constitution proclaimed that everyone who was born on Armenian territory "has the honour to be named Armenian" regardless of his nationality and religion. To speak and read, Armenian was compulsory (Article 2).

In the draft, Labor and Education were not only freedom and rights but obligation, because Armenians were obliged to take part in the economic growth of the state, which was the basis for the prosperity of people. The care for scientists, inventors, teachers and other professionals was considered to be the state's obligation. Severe punishments were prescribed for crimes against Armenian statehood and Armenian Church. It was clearly prescribed that punishment was not only retribution but had an educational effect.

In the court drafted by Shahamirian, there were 24 juries, the election of 12 of them was the procedural right of the accused.

Separate articles directly obliged the Armenian House to take care of and educate the illegally born children and children who lost their parents, to take care of the unworkable disabled people, elders who left without care and those who were in need.

The collected means should be spent with the purpose to strengthen security in Armenia, organize and develop the education and healthcare in the state.

The head of the highest executive body was the minister-president. He is the head of the state 
- "the first official and the servant of Armenian people".

Shahamirian demonstrates great respect to the followers of the Armenian royal house. In particular, if one of the representatives of Bagratuni royal family, accepting the laws and decisions of "Armenian House", would wish to become a minister, he could be elected to that position for life, while ministers could be elected for three years period.

Very surprisingly the $3^{\text {rd }}$ Article of "Vorogayt Parats" is actual: "Everyone regardless male or female... are equally free in their actions, no one has the right to rule the other". This norm of the Constitution is constant to John Lock's philosophical ideology on human freedom by the provision that natural human condition is the condition of absolute freedom. "Freedom is the behaviour not forbidden by the law - to follow his own wishes and not to be dependent on some other self-willed person's non-stable, non-definite and unknown will" (Lock, 1962, pp. 6-17).

Armenian people's wisdom proclaims: "You are free, but is not free to disturb others' freedom".

The $5^{\text {th }}$ Article is admiring: Everyone living on Armenian land with the tradition under which he worships the Lord, with the same strength he stays true to his belief and no one regardless who does not have right to be an obstacle for him. In an obvious way and clearly is defined as the right to freedom of conscience in today's concept and definition.

The $8^{\text {th }}$ Article of the draft is titled: "On the right of an Armenian to buy and sell lands". It determines: "Everyone, who is Armenian by his nationality and member of the Armenian community, christened by Christ and believer of Christ, can buy land as property and sell it only to representative or representatives of his nation and his religion".

Everything is said clearly and simply.

If all the Armenian people had the right to vote, the right to be elected was prescribed only to men population having Armenian nationality and Armenian Christian religion: “... A respectable and humble man, having Armenian nationality, who is Christ's worshipper under the religion of the Armenian Holy Church, and born in Armenia" (Article 14).

It was prescribed that the members of parliament from each voting house should receive half silver monets annually, totally six thousand silver monets in order to be free of domestic arrangements and to be able to devote their time freely to the implementation of decisions and actions directed to people's prosperity. For the election of all the officials as a compulsory requirement was prescribed: "to be Armenian national and Armenian Holy Church's worshipper". The $4^{\text {th }}$ Article in the Constitution on the Armenian religion is considering as an honour the worshipping ritual of Armenian Holy Church, that is faithfully preached to us "from the patriarchic Vaghrshapat our patriarchic highest chair - Ejmiatsin's lightning Holy Church, by the truthful voice of Armenian patriarch". The Armenian national who being christened betrayed his belief was convicted to death.

Unique content and sense have the $126^{\text {th }}$ Article prescribing the description of money. It is titled "On the form of money" and required that the text "Prosperity to Armenian people" was written on a coin. Everyone who would come in touch with coins, by reading the mentioned text should vividly understand that money should, first of all, serve to the Armenian Statehood and Armenian people's prosperity. 
In "Vorogayt Parats" (Article 82) it was prescribed that before a church wedding, spouses should sign a marriage contract, “... so that we can accept the blessing of our Creator Lord by the hand of the clergy of Armenian Holy Church, in order to grow and breed, to serve to our Lord, for the sake of high and caring Armenian state". If one of the spouses "reject and not perform his duties on due implementation of the contract he is obliged to pay five thousand monet to Armenian almshouse". The growth and reproduction of the nation are also prescribed as a compulsory provision, as national and state interest.

The $118^{\text {th }}$ Article is obliging the parents to buy one gun and one sword at their own expenses for their children who become 18 years old, as the first heritage.

On the whole territory of the Armenian state, all people are obliged to have two teachers for 25 houses, one of the teachers - to teach children reading and writing Armenian, the other to teach military service to male children (Article 101).

The draft of Constitution prescribes the requirement to leave the land undeveloped, every year the lands should be ploughed, sowed and fertilized on the proper time to receive a good harvest. And if someone is leaving the lands and gardens undeveloped, the plough and sow of the lands are implemented by the state. And if after that, the owner of the land does not solve the problem with the land, i.e. does not develop it, that land is becoming the ownership of the Armenian House.

If a person is suffered hooliganism or theft of is property, the ruler of the region, after getting confident in those facts, is obliged to restore the suffered material damage to the person, to take measures to find out punish and offender and to receive the restored money (Article 112).
As we see, the state assumes the obligation of restoring the damage caused to a person by the crime, because the state is undertaking the responsibility to eliminate the consequences of the crime committed against persons on his territory, and to recover the damage. It is obvious that Shahamirian is of the opinion that each state must keep his citizens away from criminal offences. By the recovery of the material damage caused by the crime among certain officials is increased the level of responsibility of solving the crime in order be able, alongside with punishing the offender, to recover the amounts paid from the state funds.

In the constitutional legal norms researched by us, partially such substantive solution we observe in the Constitution of Japan adopted in 1947. Namely, the $17^{\text {th }}$ Article says: "Every person may sue for redress as provided by law from the State or a public entity, in case he has suffered damage through illegal act of any public official." The given constitutional legal provision refers only to those cases when the damage has been caused by the illegal act of any public official, and the damage recovery is implemented in accordance with procedural means and through judicial decisions.

According to the $3^{\text {rd }}$ Article of the RA Constitution of the $6^{\text {th }}$ of December, 2015, together with amendments, the state is providing the protection of fundamental rights and freedoms of persons and citizens, including the protection of the right to property. The European Court of Human Rights specifying the frameworks of the state obligations in the protection of the right to property guaranteed by the $1^{\text {st }}$ article of the European Convention on Protection of Human Rights and Fundamental Freedoms developed further the idea of the state's positive obligations. It means that real and effective implementation 
of the right to property also requires certain positive measures; in particular when there is a link between the effective performing of person's right to property and the measures that a person may legitimately expect from the state to take.

That expectation also relates to a lawful obligation of the state to protect persons and citizens right to property from criminal offences. We are underlining that the recovery of caused damage in all cases is implemented under the judicial procedures, and it also should be mentioned that often this is happening after long court bureaucracy and may last for years.

Shahamirian in "Vorogayt Parats" is defining very simplified administrative procedure, and in particular, the following is said: "The administrator of the province takes the oath from him (the aggrieved person) on Holy Testament to get ensured that a man has lost his property, and, as an administrator of the province, he is obliged to recover the value of the lost property to that man, then search and find the thief or hooligan in order to receive back the amounts recovered and judge according to the law" (Avagyan, 2002).

All types of documents, both commercial and contractual, regardless of who has signed it, if contradicting to Armenian legislation and vital natural functions of a human, are recognized to be non-valid. The law obliges the state also to undertake the protection of everyone, who is living on his territory, and if he is captured, Armenian state "is obliged to save him and to return to his house and family" (Article 138).

To every Armenian resident is prescribed the right to bring a claim at court against any person without exclusions, including officials. Penitentiaries, dark prisons should be clean and comfortable not to harm the prisoner's health and constant to the actions of the offender (Article 153).
Shahamirian's legal definitions regarding women are unique. In particular, he says: "Females should not be captured, no matter Christian or pagan... female individuals cannot be enforced if they do not commit a crime". And in the $371^{\text {st }}$ Article, the servants upon the order of princes or high officials are forbidden to enter females rooms, especially married women's rooms, because these rooms are «sacred and sinless and we want no noise, conflict disturbs our mothers and women who gave birth to our sons. Excluding the cases when a criminal offender or someone punished to death should be arrested".

As we see, "Vorogayt Parats" is a new level of Armenian political and constitutional legal thinking and has a unique value in the world's constitutional culture. From this work, patriotism is radiated. That was a flight of social-political thinking, and it was seemingly the only possible strong progressive idea of anti-serfdom and Republican order in the $18^{\text {th }}$ century Armenia under Turkey's and Iran's rule, the realization of which should be desired.

Shahamirian is considering himself as "one of the least worthies and the most humbles in Armenian land, and writing the constitution of his state he does not expect anything for himself, neither power, nor prosperity, nor glory", but he is guided only "by love towards his own nation and our country".

Hakob Shahamirian died at the age of 29 in Malacca of Malaysia, where he had vast holdings of cigarette. On his cemetery is written: "Welcome to you, who read the word on my cemetery, tell me about the freedom of my nation I always desired, if someone among us has been elevated as a savour and a ruler that I desired forever and severely in the world..." (Aghjean, 1993, pp. 215-225). 


\section{REFERANCES}

Aghjean, M. A. (1993). Handipumner (Meetings, in Armenian). New York.

Arghutyan, H. (n.d.). Matenadaran, dzeragir tiv 2949 ev 1778 noyemberi tr.-i namak (Matenadaran, manuscript number 2949 and the letter of November tr. 1778, in Armenian).

Avagyan, R. (2002). Hay iravakan mtqi gandzaran (Treasury of Armenian Legal Thinking, in Armenian). (Vol. 2). Yerevan.

Ayvazyan, S. (2013). Nachala zakonodatel'nogo prava Armenii (The Basis of Armenian Legislative Law, in Russian). Yerevan: Avt. izd.

Finkelstein, G. (1969). The Laws of Ur-Nammu. Journal of Cuneiform Studies, XXII, 66-82.

Flavius, J. (1996). Evreiskoe staroslovie (Antiquities of the Jews, in Russian) (Vol. 1). Moscow.

Gurney, O. R., \& Kramer, S. N. (1965). Two Fragments of Sumerian Laws. Assyriological Studies, 16, 13-20.

Hovhannisyan, H. H. (2001). The Arguments of Force and the Force of Arguments (Violence and Progress) in Armenian Enlightenment Thought. In V.Cossy et
D.Dawson (Eds.), Progrèss et Violence au XVIII Siècle (pp. 145-163). Paris: Honore' Champion Editeur, Diffusion hors France: Editions Slatkine Gene've.

Kramer, S. (1954). Ur-Nammu Law Code. Orientalia, 23(1), 40.

Lambert, W. (1996). Instructions of Shuruppak: Babylonian Wisdom Literature. Winona Lake, Indiana: Eisenbrauns.

Lock, J. (1962). Izbranniye filosofskie proizvedeniya (Selected Philosophical Works, in Russian) (Vol. 2). Moscow.

Nelson, T. (2010). Nelson's Complete Book of Bible Maps and Charts (3rd ed.). Nashville: Thomas Nelson Publishers.

Nersesyan, M. (1990). Armyano-russkie otnosheniya $v 18$ veke, sbornik dokumentov 1760-1800 (Armenian-Russian Relations in 18th Century, Collection of Documents of 1760-1800, in Russian ) (Vol. 4). Yerevan: Institute of History of Armenian SSR.

Shahamiryan, Sh. (1773). Girk Anvanial Vorogayt Parats (The Book which is Named the Snare of Glory). Madras.

Yeritsyan, A. (1883). (1841-1902) Hndkastani harust ktaknery (Indian Rich Inheritances, in Armenian). Caucusus, 94. 


\title{
FEATURES OF FUNDAMENTAL RIGHTS IN THE CONTEXT OF THE PHILOSOPHY OF LAW
}

\begin{abstract}
The article explores the notion and peculiarities of fundamental rights of the individual in the modern, legal state. In this research, the author implements versatile, holistic, systematical (methodical) analysis of content and distinguishing features of the structural elements of the concept "legal status of the individual". Therefore, the theoretical and practical research of problems of development of fundamental human rights gives an opportunity to find new solutions in protections of relations concerning the individual's legal status.

This study is also focusing on various approaches of well-known jurists on the essence, content and legislative consolidation of the fundamental rights of the individual.

The author comes to a conclusion that in recent decades, the philosophy of law (with the theory of state and law) took under its active protection and guardianship man with his rights, freedoms and legitimate interests, and which have ceased to be the subject of national legislation's regulation, and moved to the international legal platform. Consequently, the government is obligated to guarantee fundamental human rights and freedoms. Hence, theoretical, methodological and practical analysis of problems of the individual's legal status and elaboration of suggestions concerning the enhancement of national legislation, is one of the most actual problems of jurisprudence.
\end{abstract}

Keywords: fundamental human rights and freedoms, the legal status of the individual, legitimate interests, globalization, duties, citizen, democratic state, government.

A democratic, legal, and social state is a form of human coexistence where there are mutually agreed human relations, where the state and society assume a mutual obligation to help those in need, to influence the distribution of material goods, based on such principles of justice that guarantees of a decent life are created for everyone, as well as rights, freedoms and legitimate interests are protected (Harutyunyan, 2005, pp. 110-112; Yeritsyan, 2007, pp. 106-108). Consequently, the study and clarification of the concepts of human rights and fundamental free- doms, which are at the core of a person's legal status, are at the heart of the theory of modern philosophy of law (Huymens, 1995). Moreover, it is necessary to conduct a comprehensive study of the essence and content of rights, freedoms, legitimate interests of the individual in a modern democratic state. The system of rights, freedoms, legitimate interests and obligations that form the core of a person's legal status, as well as guarantees of their protection, is based on the fundamental principle of values, according to which a person is the highest value in the Repub- 
lic of Armenia. Moreover, the inalienable dignity of a person is an integral basis of his or her rights and freedoms.

The legal status of a person includes a combination of the rights, freedoms, duties and legitimate interests of the person, which, in turn, is a means of legal regulation that regulates the social status (position) of the person.

It is noteworthy that some of the modern legal scholars consider rights, freedoms and obligations as the main elements of the legal status of a person, and legitimate interests as additional (or derivative) ones (Rideau, 2003, pp. 23-24; Vitruk, 2008, p. 105).

In our opinion, this division of rights, freedoms, and duties has contributed to the humiliation of the essence of legitimate interests, as well as their important role in law, as a result of which this concept continues to be poorly studied in the legal literature. Based on the above, we propose to consider the rights, freedoms, duties and legitimate interests of the individual as the main elements of the legal status of the individual in the context of the philosophy of law.

\section{Analysis of the Fundamental Rights and Freedoms of the Individual}

It is obvious, that in the states which stand in the way of democracy, the rights and freedoms of the individual are not stationary and eternal, but are constantly changing and developing concepts (Marchenko, 2014, pp. 204-206; Trion, 2012, pp. 105-107). In addition, the basic rights and freedoms of the individual are not assigned by the state, since they do not exist because of formal consolidation, which is also very important, but because of the social capabilities of the person arising from the system of social relations. Furthermore, the source of individual rights and freedoms in a democratic society are real social relations, not the will of the legislator.

The conducted research shows that the social capabilities of the individual are social prerequisites for the formation, the regularity of development and the ability to use the advantages of legal rights, freedoms, legitimate interests, as well as the real content of duties. Therefore, a person's rights and freedoms are the social opportunities of the person enshrined in the law to possess certain goods to meet his or her needs. Moreover, legal rights and freedoms of a person acquire clear boundaries as a result of the state's implementation of legal regulation, and violation of these boundaries by a person is considered as illegal behaviour. In this case, of course, the legislator only considers the social opportunities to meet the needs of mankind, which, by stipulating in the norms of coexistence of public life, formally acquire the opportunity to be called human rights. Moreover, ideas about human rights, penetrating into the human masses, turn into a powerful material force, and for the state there is a need to fix the list of human rights determined by historical development in the law, that is, to establish the rights of a citizen as the legal rights of a person.

The idea of human rights also has a substantive basis, which was studied by K. Marx and F. Engels. They, considering man as a "result of history" and simultaneously leading the political and civil life of the subject, define the natural rights of the individual as historically formed bourgeois-democratic rights and freedoms, where the individual and the citizen are private owners (Marx \& Engels, 1955, pp. 390-391)

Taking the above idea as a basis, as well as the analysis of the material justification of human rights and social content, many soviet lawyers, such as I. Farber and G. Malcev (1969) be- 
gan to distinguish basic human rights from the rights of a citizen (pp. 26-27).

According to P. Nedbaylo (1965), the socio-political preconditions formed in the state and society are crucial to the formation of legally recognized, inalienable rights and freedoms of a person.. In this context, L. Voevodin (1997) rightly points out, that the real content of human rights as a socially conditioned opportunity, which in its essence is a requirement for the possession of certain social benefits (p. 115).

Meanwhile, V. Kartashkin (2018) proposes to distinguish the fundamental rights and duties of citizens (social category) from constitutional rights and responsibilities (legal category) (pp. 48-49). Based on the conducted research, we consider, V. Kartashkin's that approach to fundamental rights is exaggerated and may complicate the process of defining, examining the substance, content and elements of a person's legal status. Moreover, these opportunities for the person exist before their legislative confirmation.

According to the universally recognized definition, human rights are an opportunity to determine the extent of one's own behaviour. All other persons, public authorities, organizations must refrain from interfering with this behaviour (Ayvazyan, 2008, p. 12).

At the same time, various definitions and comments on fundamental human rights and freedoms can only be accepted partially and with certain reservations, since they generally do not fully reflect the essence and content of this concept, for example, according to Yu. Troshkin (1998), the fundamental rights are only those rights that are enshrined in the Constitution and the most important human rights documents, define the ideals of humanism in society, limit the power and protect people from their arbitrariness (pp. 30-31). Therefore, this definition is narrow in content, since it does not fully disclose the essence and meaning of fundamental rights.

Moreover, studies have shown that, due to modern political and legal processes, individual rights and freedoms are gradually becoming a standard for the development of society, the establishment of the idea of the rule of law and a stable factor in international legal cooperation.

In the modern world, the category of universal (fundamental) rights of the individual has been formed in the context of the universal equality of people, which has a common, generally accepted and legal meaning for the world community (Loth, 1998, pp. 22-24).

It is obvious that human rights and freedoms have ceased to be an object of domestic policy and practice of the state, and have become a problem of the entire international community.

Nowadays, the scope of individual rights and freedoms is determined not only by the specific characteristics of a particular society but also by the development of the civilization of all mankind, as well as the degree and level of integration into the international community of a given state. Therefore, fundamental rights become a high level in the international legal plane, below which any state, claiming to be a democratic, legal and social state, cannot descend. It is undeniable that a new phase in the history of human rights began after World War II when the processes of cooperation and integration of states developed and human rights gained universal recognition through international joint affairs. Thus, the UN General Assembly adopted the Universal Declaration of human rights (10.12.1948), which became the first-ever international universal document on the list of human rights and fundamental freedoms.

Thus, human rights are basic (fundamental) rights that are universal (extend to all who be- 
long to the biological type of Homo sapiens) and which are egalitarian (all are equal), as well as ensure a dignified life and development of the person in the context of the achievements of modern historical-social progress (Ebzeev, Aybazov, \& Krasnoryadtsev, 2006, pp. 54-57).

Considering a modern democratic, legal, social state, it becomes obvious that the priority of norms and principles of the internationally recognized human rights law in relation to domestic norms and principles is a categorical imperative of the international community.

At the same time, we agree with the opinion formed in recent years in the judicial literature and philosophy of law that the process of globalization cannot be the reason for the universalization of human rights, because the right to preserve the native language, culture, customs is the natural, inalienable right of every nation, ethnicity (Vencent 1989, pp. 49-54).

In our opinion, human rights and freedoms must correspond to the needs of a particular society and can have multiple forms of expression.

H. Behruz and M. Monshipouri rightly pointed out, that only those individual rights that correspond to the social problems of the society take into account cultural characteristics, religious traditions and beliefs, the accumulated experience of previous generations, and the moral principles of society can be recognized as universal rights (Behruz, 2006, pp. 20-22; Monshipouri, 1994). Consequently, there are objective justifications for both doubts and opposition to the universal nature of fundamental human rights.

First of all, there are regional, civilizational, and cultural differences in which people are born, raised, act, and think (Islamic, Jewish, etc.).

Second, there is a significant difference in the social conditions where people live in differ- ent countries, regions and continents.

Third, mutual disrespect for national and religious values in immigration processes.

It is hard to agree with the opinion of several modern researchers that the list of human rights and freedoms enshrined in a number of declarations on fundamental human rights and freedoms including the Universal Declaration of Human Rights (1948), the European Convention for the Protection of Human Rights and Fundamental Freedoms (1950), International Covenant on Civil and Political Rights (1966), is based solely on European values (Mutua, 2002, pp. 8283; Mattelman, 1996, p. 110). It is no coincidence that regional acts such as the American Convention on Human Rights (1969), the African Charter on Human and People Rights (1981), the Arab Charter of Human Rights (1994) are anchored not only on Universal Declaration of Human Rights but also on other human rights acts. Definitely, the organizations, which adopt those documents, take into consideration cultural characteristics and do not exclude other interpretations of international human rights norms. Actually, in all cases, there are even fundamental differences between the principles and reality proclaimed in international legal and regional instruments. For example, the status of women in Islamic countries, "inviolable" in India.

Therefore, progress is realized in any cultural civilization, in the process of gradual convergence of perception and implementation of the fundamental principles of human rights and, of course, is facilitated by the globalization of economic and law, immigration, exchange of cultural values, solution of global problems related to drug trafficking and the fight against international terrorism, natural and man-made disasters. 
In our opinion, there should be progress on the path of social and humanistic development and not the destruction of traditional values and the fall into prehistoric society.

On this issue, E. Lukasheva (2006) noted that the artificial acceleration of the process of adoption of international human rights norms, which contradicts the political, customary, cultural ideas of individual countries, regions is impermissible.

Therefore, we consider that it is necessary to respect a different world order and not try to change it through universal democratic and forcible implementation of human rights standards. It is important to have a constant dialogue of civilizations, a gradual and long-lasting process of perception, and adaptation to generally accepted norms and values, which opens the way to preserving the diversity and richness of the world.

It is known that those rights and freedoms that are more vital for the individual, society, and the government are enshrined in the Constitution and are called "basic rights and freedoms".

For example, Chapter 2 of the Constitution of Republic of Armenia: "Basic Rights and freedoms of the Human Being and the Citizen" includes such fundamental rights and freedoms of persons living in the territory of RA as the right to life, right to physical and mental integrity, the right to inviolability of the home, freedom of thought, conscience and religion, freedom of expression of opinion, right to judicial protection and the right to apply to international bodies for the protection of human rights etc. In addition, in Armenia, basic rights and freedoms of the human being and the citizen are regulated by other branches of law, which are not considered fundamental in their content, and therefore do not receive constitutional protection. Furthermore, rights enshrined in the current legislation specify, supplement and develop constitutional rights, which are based on the latter, and thus don't diminish the significance of constitutional rights and freedoms, their direct effect. For example, on the basis of these constitutional norms, the Criminal Code of RA contains many norms regarding sanctions provided for violations of the basic rights and freedoms of citizens. Moreover, according to article 81 of the Constitution of RA, the practice of bodies operating on the basis of international treaties on human rights, ratified by the Republic of Armenia, shall be taken into account when interpreting the provisions concerning basic rights and freedoms enshrined in the Constitution.

This leads to the conclusion that sectoral rights Supplement constitutional rights also for the reason that the latter are designed to fully cover the legal capacity of the individual in all spheres of various social relations, are independent and run parallel to the constitutional rights.

Consequently, branch rights supplement constitutional rights also because they are meant to fully cover a person's legal capacity in all areas of social relations, are progressing in parallel and independently of constitutional rights.

In other words, the ratio is not a ratio of whole and part, since both the basic and the rights established by the rules of the branches of law are independent. The correlation between these two groups of rights is that basic rights determine the content and main role not only of a particular right but also of the entire human rights system. Basic rights are rights that belong not to a particular group of people, but to each person. Therefore, we can say with confidence that basic rights are not only constitutional but also subjective rights. 


\section{Conclusions}

Summing up the results of explored issues and considering the fundamental rights as a dynamic phenomenon of the philosophy of law, we conclude that it is necessary to consider the rights of the individual, based on the combination of social conditions in this society and the state and the legal norms built on their basis. Social opportunities for a person enshrined by the state in the Constitution and laws become legal requirements that are subject to the protection (guarantee) of the state. Moreover, human rights are an opportunity to determine the extent of one's own behaviour. As a result of our research, we have come to the simple conclusion, that if a specific fundamental human right is not enshrined in the Constitution of a state, then it must be recognized in that state, regardless of its constitutional provision.

It is obvious that basic human rights are the inalienable, socially necessary opportunities guaranteed by the government, to freely, consciously and responsibly possess the vital material and spiritual goods.

\section{REFERENCES}

Ayvazyan, V. (2008). Mardu iravunqner (Human Rights, in Armenian). Yerevan: Tigran Mets.

Behruz, H. (2006). Evolyutsiya islamskogo prava: teoretiko-sravnitel'noe issledovanie (The Evolution of Islamic Law: a Theoretical and Comparative Study, in Russian). (PhD dissertation). Odessa.

Ebzeev, B., Aybazov, R., \& Krasnoryadtsev, S. (2006). Globalizatsiya i gosudarstvennoe edinstvo Rossii (Globalization and
State Unity of Russia, in Russian). Moscow: Formula prava.

Farber, I. (1967). Prava cheloveka, grazhdanina i litsa v sotsialisticheskom obshchestve (Human Rights, Citizen and Person in a Socialist Society, in Russian). Jurisprudence, 1, 39-46.

Harutyunyan, G. (2005). Sahmanadrakan mshakuyt. Patmutyan dasery yev zhamanaki martahravernery (Constitutional Culture: the Lessons of the History and the Challenges of the Time, in Armenian). Yerevan: Nzhar Publishing.

Huymens, J. (1995). Post-Cold War Imposion and Globalisation: Liberalism Runnig Past Itself. Millennium: Journal of International Studies, 24(3), 88-87.

Kartashkin, V. (2018). Prava cheloveka: mezhdunarodnaya zashchita $v$ usloviyakh globalizatsii (Human rights: international protection in the context of globalization, in Russian). Moscow: Norma.

Loth, W. (1998). The Division of the World 1941-1945. London: Routledge.

Lukasheva, E. (2006). Prava cheloveka. Konflikt kultur (Human Rights. The Conflict of Cultures, in Russian). Russian justice. 6, 15-24.

Malcev, G. (1969). Sotsialisticheskoye pravo $i$ svoboda lichnosti (teoreticheskiye voprosy). (Socialist Law and Personal Freedom (Theoretical Issues), in Russian). Moscow: Yuridicheskaya literatura.

Marchenko, M. (2014). Teoriya gosudarstva $i$ prava. (Theory of State and Law, in English) (3rd ed.). Moscow: Yurayt.

Marx, K., \& Engels, F. (1955). Sochineniya (Works, in Russian) (2nd ed., Vol. 1). 
Moscow: State Publishing House.

Mattelman, J. (1996). Globalization: Critical Reflactions. New York: Lynne Rienner pub. Boulder.

Monshipouri, M. (1994). Islamic Thinking and the Internationalization of Human Rights. The Muslim World, LXXXIV, 217-239.

Mutua, M. (2002). Human Rights: A Political and Cultural Critique. Philadelphia: Philadelphia Univ. Press.

Nedbaylo, P. (1965). Aktual'nye voprosy sovetskoi yuridicheskoi nauki (Actual Issues of Soviet Legal Science, in Russian). Abstracts of the Republican Interuniversity Scientific Conference Dedicated to the Problems of Soviet Law (p. 5). Odessa: Publishing house of the State University I.I. Mechnikov.

Rideau, J. (2003). Droit institutionnel de l'Union et des Communautes Europeennes. 4ème éd.. Paris: L.G.D.J.

Trion, N. (2012). Théorie générale du droit:
Droit, pouvoire, savoir. 2ème éd. Paris: Lancier.

Troshkin, Y. (1998). Prava cheloveka (Human Rights, in Russian). Moscow: Polygraphouse of Administration of Moscow reg.

Vencent, R. (1989). Human Rights and Iternational Relations. Cambridge: CUP.

Vitruk, V. (2008). Obshchaya teoriya pravovogo polozheniya lichnosti. (The General Theory of the Legal Status of a Person, in Russian). Moscow: Norma.

Voevodin, L. (1997). Yuridicheskiy status lichnosti $v$ Rossii (The Legal Status of a Person in Russia, in Russian). Moscow: Norma.

Yeritsyan, A. (2007). Mardu iravunqneri yev drants pashtpanut'yan himnakhndirnery globalizatsiayi darashrjanum (Problems of Human Rights and their Protection in the Age of Globalization, in Armenian). Yerevan: Heghinakayin hratarakchutyun. 